\title{
Management of Emotional Intelligence of Samapta Bhayangkara Members Against Demonstrations for Law Enforcement
}

\author{
Sudarto $^{1}$, Suparno ${ }^{2}$ \\ \{remobjos@gmail.com¹, suparno@borobudur.ac.id² \\ Program Doctor of Law, Universitas Borobudur ${ }^{1}$, Faculty of Law, Universitas Borobudur ${ }^{2}$
}

\begin{abstract}
The duties and functions of Samapta Danangkara in guarding the peace and order of the community are complicated, considering that every time there are demonstrations or riots, it is the members of the Sabhara who are tasked with securing public facilities from the tantrums of the masses. The purpose of writing this article is to find out how the police have managed emotional intelligence against Sabhara members in calming demonstrators. The method used in this article is empirical juridical with action and descriptive approach. The results obtained from this study are that the Indonesian National Police has developed a technique for managing emotional intelligence for Sabhara members so that Sabhara members have a relatively stable emotional level despite the many obstacles they face.
\end{abstract}

Keywords: Emotional Intelligence; Samapta Bhayangkara; Law Enforcement; Demonstrations

\section{Introduction}

To carry out its primary duties in general, the National Police has five police operational functions that have their respective responsibilities: the Intelligence function, the Investigation function, the Traffic function, the Community Guidance function, and the Samapta Bhayangkara function [1]. The role of Samapta Bhayangkara, which is better known by the public as the Sabhara Polri unit, is one of the operational, technical functions of the National Police, which carries out the main task of being preventive or preventive. Patrol, regulation, guard, escort, and community service are essential tasks for this unit, whose main objective is to eliminate or at least minimize the convergence of intentions and opportunities for violations or crimes to occur [2]. The Indonesian National Police (POLRI) is a state instrument responsible for carrying out internal security, including carrying out the main tasks of maintaining public safety and order, law enforcement, and protecting, nurturing, and serving the community [3]. Number 2 of 2002 has main tasks, including maintaining public security and order, enforcing the law, and providing protection, protection, and service to the community.

The tasks carried out by members of the National Police who carry out the Sabhara function are generally service tasks to the community, which in their implementation are in 
direct contact with the district. Among these tasks, Mass Control (Dalmas) is one of the tasks most vulnerable to clashes between the police and the communities they serve. Mass control is part of the task of the Samapta police, which is an activity by providing protection, protection, and service to a group of people expressing their opinions or aspirations in public to prevent the influence of particular parties or provocateurs from entering [4]. Anarchic actions taken by individual participants in the demonstration sparked clashes, resulting in beatings by members of the National Police on duty. In this action, the police officers have committed violations and are a form of a breach of human rights. Therefore, the National Police, especially members of the Sabhara who are in charge of dealing directly with the masses or demonstrators, are required to control their emotions so that anarchic actions do not easily provoke them [5].

The critical thing to observe in the recurrence of cases of violence involving members of the National Police is the level of emotional stability, maturity of thought, and peace of mind. There are many factors why members of the National Police do such things, including anger at the condition, hopelessness, and feeling that they have been poorly treated. Attention to this emotional aspect is time to increase. One approach to emotion is the concept of emotional intelligence. Emotional intelligence is the ability to motivate oneself and endure frustration, control impulses and not exaggerate pleasures, regulate moods and keep stress from crippling the ability to think, empathize and pray. Emotional intelligence is divided into five main aspects: recognizing one's own emotions, managing emotions, motivating oneself, recognizing other people's feelings, and building relationships.

People who have high emotional intelligence can understand and manage their feelings, motivate themselves, and empathize and build relationships with others will have an advantage in all areas of life, both in love and friendship relationships or in success - her job. A person with high emotional skills means that he is most likely to be happy and prosperous in his life. Freedom to express opinions in public is a human right that has been explicitly guaranteed in the laws and regulations in Indonesia. Freedom of expression is the embodiment of democracy in the life of the nation and state. Freedom to express opinions is essential to be guaranteed because it is a means for citizens to defend their human rights or demand other human rights that should be fulfilled by the state and oversee the running of government and public bodies. Suppose there are internal regulations from an agency, university, or company that prohibit the expression of opinions in public, of course. In that case, these regulations are contrary to the laws and regulations in Indonesia. An agency that imposes sanctions on participants in expressing opinions in public peacefully and under the provisions of the legislation can be said to be an undemocratic agency and violate citizens' human rights.

\section{Methodology}

The approach in this study uses an empirical juridical method. The problem is done by combining legal materials (secondary data) with primary data obtained in the field, namely about the implementation of emotional management for members of the Sabhara (Samapta Bhayangkara) in handling demonstrations [6]. This research is descriptive, namely research that describes or explains and provides data in as much detail as possible regarding the problems [7]. The data obtained from the research results will be analyzed using descriptive analysis methods that explain clearly with sentences to answer the formulation of the problem. 


\section{Results and Discussion}

\subsection{Emotional Management of Sabhara Members (Samapta Bhayangkara) in Handling Demonstrations}

During the demonstration, the police recorded the course of the demonstration using video cameras, both general and specific, during the protest. The Dalmas troops, who are also ordinary people, cannot monitor the activities carried out by individual protesters [8]. So monitoring is done using a video camera carried out by the police from the Intelkam function. Tracking with this camera is also valuable for law enforcement if certain people carry out unlawful activities [9]. At this stage, the police conduct negotiations through negotiators with the corps of protesters. Negotiators are members of the National Police who bargain with the mass of protesters to get a mutual agreement. The negotiators were in front of the Dalmas troops, in the beginning, to negotiate or negotiate with the field coordinator to accommodate aspirations. After negotiations, the negotiator reports to the local police chief about the demands for the demonstration to be forwarded to the intended party or agency. Negotiators can also accompany representatives of protesters to meet the intended party to convey their aspirations. However, suppose the protester in his claim asks the head of the agency or the intended party to come in the midst of the mass of protesters to explain. In that case, the negotiator reports to the head of the local police, requesting that the head of the agency or the intended party explain the protesters.

In providing explanations, the head of the agency or the intended party continues to be accompanied by a negotiator and the chief of the local police. Each platoon commander (Dan Ton) controls his members and is responsible to the company commander (Dan Ki), and then the company commander reports to his superiors. The control in the field is accountable to the local police chief and subsequently reports on the development of the situation to the police chief as the holder of situation control and the person in charge of security and is authorized to regulate all actions of the troops in the field at the location of the demonstration. If the situation increases from an orderly position (green) to a disorderly problem (yellow), then a replacement layer is carried out with further Dalmas. The dressing layer is a transitional activity from the initial Dalmas unit to the advanced Dalmas unit. There is the action of the police in the field of personnel to carry out open security (Sabhara and Brimob).

At this stage, the negotiators are still negotiating with the protesters as much as possible, even though the situation is no longer orderly (yellow). An intractable problem is when the protesters have started to perform actions that disturb the order and security around the demonstration site, etheric actions and similar actions that make it difficult for other community members - for example, burning something on the highway, lying on the road so that it disturbs road users. So, in this case, the Dalmas troops continued to help lift and move to a neutral and or safer place in a compelling and educative way. Advanced Dalmas are units equipped with special police equipment, mobilized in the face of disorganized mass conditions (yellow). In carrying out the dressing layer from the initial Dalmas to the advanced Dalmas, the police can use animal units with armor formation in front of the initial Dalmas to protect during the dressing process. The dressing layer is a transitional activity from the initial Dalmas to the advanced Dalmas. If the escalation escalates or the masses throw complex objects at the officers, Dalmas will continue to take refuge. Then the local police chief will appeal to Danton or Danki Dalmas to continue taking legal action as follows:

a. The mass-dissolving tactical vehicle moves forward to take action to disperse the mass. At the same time, it continues to advance by carrying out mass propulsion. 
b. Firefighters can do fire fighting, extinguishing tires, banners, flags, and other props.

c. He was throwing and firing tear gas.

Each Danton or Danki continues to report any developments in the situation to the local police chief. And if the situation escalates, the head of the local police will report to the Head of the Resort Police as the general controller so that a cross-change is carried out with the Mobile Brigade Detachment or Riot Management Company (PHH). A situation that violates the law is a situation where there have been actions that violate the law by the protesters during demonstration activities. For example, there is theft, destruction of public property or the surrounding community, intimidation, or other criminal acts. In a situation that violates the law, the control is held by the Chief of Police as the general controller after a notification from the local police chief about the problem violates the law.

The Chief of Police controls general control to regulate all forces and actions of troops in the field during demonstrations in conditions where the mass of protesters have committed unlawful acts in the form of threats, theft with violence, destruction, arson, severe persecution, terror, intimidation, taking hostages. And so on, starting now referred to as the red situation. This means that only the local police chief can exercise control over the security of the demonstration. Combating riots is a series of activities or processes in anticipating or dealing with mass riots or riots to protect community members from the access caused. At this stage, the negotiator is no longer working because the action taken is law enforcement action from the riots that occurred. PHH Brimob can take legal action based on the general controller's order. Arrests and shootings with rubber bullets are possible. Or, in an emergency, can use live ammunition. Meanwhile, the police from other functions continue to carry out their respective duties according to their procedures and coordinate to achieve maximum results. For example, the Intelkam function monitors and records all incidents during the riots to facilitate the police investigation process.

\subsection{Constraints Faced in Managing Emotions for Members of Samapta Bhayangkara in Handling Demonstrations}

The State Police Institution of the Republic of Indonesia in carrying out The task of forming public legal awareness must have internal and external factors and constraints. The supporting elements and obstacles experienced by the police are:

a. Intern Factor

1. It is found in every member of the police who can less control his emotions over the heated situation due to the demonstration.

2. Lack of police professionalism in dealing with protests.

3. The number of police personnel in the field is not balanced with the number of protesters.

4. Protesters are hard to control.

b. Extern Factor

1. In addition, the field conditions are different from the theoretical conditions, which makes it difficult for the police to secure the protesters. The protesters think that if the police arrest one of them who commits anarchy, they think that the police have stopped them, even though this was done to regulate the course of the demonstration.

2. The image of the police in the public's eyes tends to be negative so that every police action is considered wrong.

3. Public knowledge of the law needs to be increased because high public awareness of the law will reduce the possibility of riots. Information or socialization of new 
regulations needs to be done directly. Because of socialization through electronic media, not all people can access it. Counseling is carried out to increase public awareness of applicable laws to create a safe situation in society.

4. The lack of coordination is not only in the preparation stage or before the demonstration but also during the demonstration. The police, in this case, is not only security for demonstrations but also as an intermediary between protesters and the intended party or agency.

In this case, related agencies or parties must actively communicate with the police so that riots do not arise due to the protesters' dissatisfaction with the results or solutions obtained from these demonstration activities. Efforts are being made to overcome the factors that hinder the implementation of the handling of the demonstration by coordinating. Before securing a protest, it is necessary to hold a coordination meeting. Coordination is carried out either on the part of the police themselves or with the relevant agencies. During and after the demonstration, coordination continues. Another effort is to provide legal counseling to the public. Community Guidance carries out legal counseling to the community with the assistance of the police from other functions depending on the material presented. The lack of legal awareness of the community is due to a lack of knowledge of the law. Therefore, it is necessary to provide legal education to the public. Improving the quality and professionalism of police officers is also an effort to overcome obstacles. Because with the creation of professional members of the police, the possibility of violations committed to carrying out tasks such as human rights issues can be avoided.

\section{Conclusion}

In an orderly situation, Dalmas troops carried out escort and security to the protesters while continuing to appeal to the protesters. During the demonstration, the police recorded the course of the demonstration using video cameras, both general and specific, during the protest. The Dalmas troops, who are also ordinary people, cannot monitor the activities carried out by individual protesters. So monitoring is done using a video camera carried out by the police from the Intelkam function. The purpose of tracking with this camera is also valuable for law enforcement if certain people carry out unlawful activities. At this stage, the police conduct negotiations through negotiators with the corps of protesters. Negotiators are members of the National Police who bargain with the mass of protesters to get a mutual agreement. The negotiators were in front of the Dalmas troops, in the beginning, to negotiate or negotiate with the Field coordinator to accommodate aspirations.

After negotiations, the negotiator reports to the local police chief about the demands for the demonstration to be forwarded to the intended party or agency. Negotiators can also accompany representatives of protesters to meet the intended party to convey their aspirations. However, suppose the protester in his claim asks the head of the agency or the intended party to come in the midst of the mass of protesters to explain. In that case, the negotiator reports to the head of the local police, requesting that the head of the agency or the intended party clarify among the protesters. In providing explanations, the head of the agency or the intended party continues to be accompanied by a negotiator and the chief of the local police. Each platoon commander (Dan Ton) controls his members and is responsible to the company commander (Dan Ki), and then the company commander reports to his superiors. The control in the field is accountable to the local police chief and subsequently reports on the development of the situation to the police chief as the holder of situation control and the person in charge of 
security and is authorized to regulate all actions of the troops in the field at the location of the demonstration. If the situation increases from an orderly condition (green) to a disorderly problem (yellow), then a replacement layer is carried out with further Dalmas. The dressing layer is a transitional activity from the initial Dalmas unit to the advanced Dalmas unit. This is the action of the police in the field of personnel to carry out open security (Sabhara and Brimob).

At this stage, the negotiators are still negotiating with the protesters as much as possible, even though the situation is no longer orderly (yellow). An intractable problem is when the protesters have started to perform actions that disturb the order and security around the demonstration site, tether actions, and similar actions that make it difficult for other community members - for example, burning something on the highway, lying on the road so that it disturbs road users. So, in this case, the Dalmas troops continued to help lift and move to a neutral and or safer place in a compelling and educative way. Advanced Dalmas are units equipped with special police equipment, mobilized in the face of disorganized mass conditions (yellow). In carrying out the dressing layer from the initial Dalmas to the advanced Dalmas, the police can use animal units with armor formation in front of the initial Dalmas to protect during the dressing process. The dressing layer is a transitional activity from the initial Dalmas to the advanced Dalmas. If the escalation escalates or the crowd throws complex objects at the

officers, Dalmas will continue to take shelter. Then the local police chief will appeal to Danton or Danki Dalmas to take legal action.

\section{References}

[1] E. E. Supriyanto, M. Rachmawati, and F. J. Nugroho, "Transformative Policies and Infrastructure Strengthening Towards the Police Era 4 . 0,” J. Bina Praja, vol. 13, pp. 231-243, 2021.

[2] R. Samual and A. Kasim, "Strategi SDM Polri Mempersiapkan Generasi 'Y' di Era Revolusi Industri 4.0,” J. Ilmu Kepol., vol. 14, no. 3, pp. 219-230, 2020, [Online]. Available: http://jurnalptik.id/index.php/JIK/article/view/280.

[3] T. Gash and R. Hobbs, Policing 4.0 Deciding the Future of Policing in the UK. 2018.

[4] Kurnia, R. Muhammad, and Lamazi, "Peran Kepolisian Sektor Kecamatan Sajad Dalam Penanganan Covid-19 Tahun 2020," Syi 'ar J. Ilmu Komun. ..., vol. 3, no. 1, pp. 12-29, 2020, [Online]. Available: http://journal.iaisambas.ac.id/index.php/Syiar/article/view/210.

[5] E. E. Supriyanto, "Perang Strategi Pemenangan Pemilu Via Sosial Media (Sebuah Analisis Literatur Dan Sosial Media)," in Proceeding Seminar Nasional dan Diskusi Ilmiah Media, Pemilu dan Komunikasi Politik Menyambut Tahun Politik Indonesia 2018-2019, L. K. Alfirdaus and N. Hasfi, Eds. Magister Ilmu Politik FISIP Universitas Diponegoro, 2018, pp. 122-135.

[6] F. E. Hagan and L. E. Daigle, Introduction to criminology: Theories, methods, and criminal behavior. Sage Publications, 2018.

[7] C. Maguire, "Library research: Luxury or necessity?," Aust. Libr. J., vol. 60, no. 4, pp. 298-303, 2011, doi: 10.1080/00049670.2011.10722646.

[8] A. Rahardjo and H. Anwar, "Pendidikan pembentukan bintara polri dalam menyiapkan lulusan yang profesional," Iustitia Omnibus, vol. 2, no. 1, 2017.

[9] A. R. APRILIA, "Tindakan Represif Dari Polri Dalam Menghadapi Unjuk Rasa Masyarakat," 2020, [Online]. Available: 
https://core.ac.uk/download/pdf/322774886.pdf. 